REPORT TITLE: Treatment of Produced Waters Using a Surfactant Modified Zeolite/Vapor Phase Bioreactor System

REPORT TYPE: Semi-Annual Technical Report

REPORT PERIOD: 1 October 2004 - 31 March 2005

PRINCIPAL AUTHORS: Soondong Kwon, Elaine B. Darby, Li-Jung Chen, Lynn E.

Katz, Kerry A. Kinney, R.S. Bowman, E.J. Sullivan

REPORT ISSUE DATE: September 2005

DOE AWARD NUMBER: DE-FC26-02NT15461 


\title{
Treatment of Produced Waters Using a Surfactant Modified Zeolite/Vapor Phase Bioreactor System
}

Semi-Annual Technical Report

1 October 2004 - 31 March 2005

DOE AWARD NUMBER: DE-FC26-02NT15461

DISCLAIMER: This report was prepared as an account of work sponsored by an agency of the United States Government. Neither the United States Government nor any agency thereof, nor any of their employees, makes any warranty, express or implied, or assumes any legal liability or responsibility for the accuracy, completeness, or usefulness of any information, apparatus, product, or process disclosed, or represents that its use would not infringe privately owned rights. Reference herein to any specific commercial product, process, or service by trade name, trademark, manufacturer, or otherwise does not necessarily constitute or imply its endorsement, recommendation, or favoring by the United States Government or any agency thereof. The views and opinions of authors expressed herein do not necessarily state or reflect those of the United States Government or any agency thereof.

\author{
Lynn E. Katz \\ Project Manager
}




\begin{abstract}
$\underline{\text { Abstract }}$
This report summarizes work performed on this project from October 2004 through March 2005. In previous work, a surfactant modified zeolite (SMZ) was shown to be an effective system for removing BTEX contaminants from produced water. Additional work on this project demonstrated that a compost-based biofilter could biodegrade the BTEX contaminants found in the SMZ regeneration waste gas stream. However, it was also determined that the BTEX concentrations in the waste gas stream varied significantly during the regeneration period and the initial BTEX concentrations were too high for the biofilter to handle effectively. A series of experiments were conducted to determine the feasibility of using a passive adsorption column placed upstream of the biofilter to attenuate the peak gas-phase VOC concentrations delivered to the biofilter during the SMZ regeneration process. In preparation for the field test of the SMZ/VPB treatment system in New Mexico, a pilot-scale SMZ system was also designed and constructed during this reporting period. Finally, a cost and feasibility analysis was also completed.

To investigate the merits of the passive buffering system during SMZ regeneration, two adsorbents, SMZ and granular activated carbon (GAC) were investigated in flow-through laboratory-scale columns to determine their capacity to handle steady and unsteady VOC feed conditions. When subjected to a toluenecontaminated air stream, the column containing SMZ reduced the peak inlet $1000 \mathrm{ppm}_{\mathrm{v}}$ toluene concentration to $630 \mathrm{ppm}_{\mathrm{v}}$ at a 10 second contact time. This level of buffering was insufficient to ensure complete removal in the downstream biofilter and the contact time was longer than desired. For this reason, using SMZ as a passive buffering system for the gas phase contaminants was not pursued further.

In contrast to the SMZ results, GAC was found to be an effective adsorbent to handle the peak contaminant concentrations that occur early during the SMZ regeneration process. At a one second residence time, the GAC bed reduced peak contaminant concentrations by $97 \%$. After the initial peak, the inlet VOC concentration in the SMZ regeneration gas stream drops exponentially with time. During this period, the contaminants on the GAC subsequently desorbed at a nearly steady rate over the next 45 hours resulting in a relatively steady effluent concentration of approximately $25 \mathrm{ppm}_{\mathrm{v}}$.
\end{abstract}


This lower concentration is readily degradable by a downstream vapor phase biofilter (VPB) and the steady nature of the feed stream will prevent the biomass in the VPB from enduring starvation conditions between SMZ regeneration cycles. Repetitive sorption and desorption cycles that would be expected in the field were also investigated. It was determined that although the GAC initially lost some VOC sorption capacity, the adsorption and desorption profiles stabilized after approximately 6 cycles indicating that a GAC bed should be suitable for continuous operation.

In preparation for the pilot field testing of the SMZ/VPB system, design, "inhouse" construction and testing of the field system were completed during this project period. The design of the SMZ system for the pilot test was based on previous investigations by the PI's in Wyoming, 2002 and on analyses of the produced water at the field site in New Mexico. The field tests are scheduled for summer, 2005.

A cost survey, feasibility of application and cost analyses were completed to investigate the long term effectiveness of the SMZ/VPB system as a method of treating produced water for re-use. Several factors were investigated, including: current costs to treat and dispose of produced water, end-use water quality requirements, and state and federal permitting requirements. 
TABLE OF CONTENTS

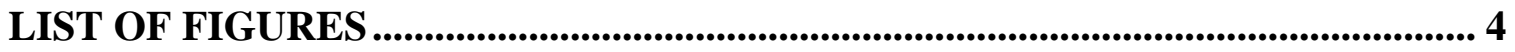

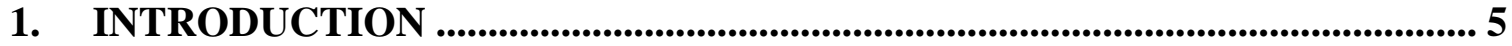

2. BUFFERING EXPERIMENTS - MATERIALS AND METHODS .................... 6

2.1 BUFFERING COLUMN DESIGN AND OPERATION …................................. 7

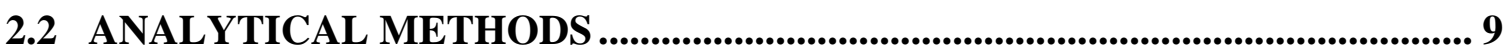

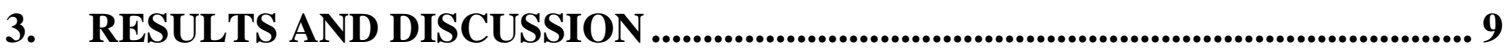

3.1 BUFFERING TESTS WITH SMZ …................................................................... 9

3.2 BUFFERING TEST WITH GAC …….............................................................. 11

4. PILOT-SCALE SMZ SYSTEM DESIGN ......................................................... 16

5. COST SURVEY, FEASIBILITY AND COST ANALYSIS................................ 19

5.1 COST SURVEY

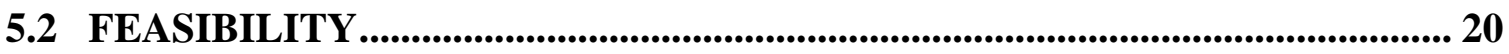

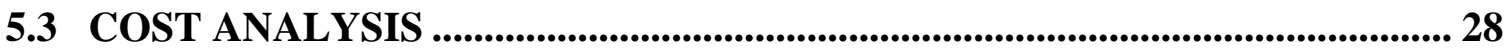

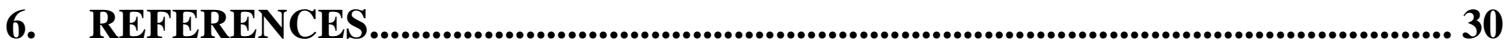




\section{List of Figures}

Figure 1 - Pre-saturation of SMZ with toluene

Figure 2 - Response of the SMZ buffering column to a spike in toluene concentration at time 0 .

Figure 3 - Pre-saturation of GAC with toluene. ........................................................ 12

Figure 4 - Toluene spike feed test in the GAC buffering column. ........................... 13

Figure 5 - Toluene concentration entering the GAC buffering column during each toluene spike test.

Figure 6 - (A) Response of the GAC buffering column to repeated toluene spikes; (B) Outlet toluene concentration plotted on a smaller scale to show detail.

Figure 7 - Schematic diagram of SMZ reactors treating produced water.................17

Figure 8 - Schematic diagram of a saturated SMZ column being regenerated via air sparging. 


\section{Introduction}

The United States oil and gas industry generates more than three billion tons of wastewater annually (API, 1987). This water is often called 'produced water' and can be characterized as saline water that contains a variety of pollutants, including soluble and insoluble organics as wells as many inorganic species. Several of the dissolved contaminants, namely benzene, toluene, ethylbenzene, and xylenes (BTEX), are known to be hazardous at low concentrations. Current treatment methods for produced water focus on the recovery of insoluble oil and grease that are of economic value to the producer. However, these treatment procedures are ineffective at removing dissolved organic and soluble inorganic compounds. Due to the harmful constituents remaining in produced water after oil/water separation, regulation of produced water disposal may soon become more stringent. The need for an innovative, cost-effective method for treating produced water therefore exists. Moreover, many oil and natural gas production operations are located in arid environments, where water is extremely valuable. The ability to reuse produced water in agricultural and transportation operations would be of great benefit to local communities. This research focuses on the use of a surfactant modified zeolite (SMZ) / vapor phase bioreactor (VPB) system to treat produced waters.

SMZ's relatively low cost and ease of regeneration makes it a promising option for field-scale treatment of produced waters, as well as many other multi-component waste streams. A key feature required for successful application of SMZ to the treatment of produced water is the regeneration of the SMZ. Studies completed by the PIs indicate that SMZ can be readily regenerated for BTEX compounds simply by sparging ambient air through the SMZ column. This process generates a moist air stream contaminated with volatile organic compounds (VOCs) including BTEX. Because these VOCs are biodegradable, a vapor phase bioreactor (VPB) can be used to destroy the pollutants generated in the SMZ regeneration step. Products of VPB biodegradation include carbon dioxide, water and new biomass. The effectiveness of the SMZ/VPB combination may be affected by several factors such as: the interaction of multiple VOCs presented in the inlet gas stream, the microbial population present in the biofilter and the availability of nitrogen. In addition, VPBs prefer a continuous feed stream and thus the operation of the 
SMZ/VPB system will need to be optimized to match SMZ regeneration and VPB feed cycles.

Recent experiments completed by the PIs indicate that a compost based biofilter could successfully biodegrade the BTEX contaminants found in the SMZ regeneration waste gas stream. The biofilter was also found to tolerate short periods without a feed waste gas stream. This feature will be important when the biofilter is coupled to the SMZ beds and only receives a waste gas when an SMZ bed is actually being regenerated. However, regeneration tests with the SMZ indicate that the BTEX concentrations in the waste gas stream vary significantly during the regeneration period and the initial BTEX concentrations are too high for a VPB to handle effectively. To attenuate the peak concentration of VOCs expected during the early stages of regeneration, a series of experiments were conducted to determine whether placing a passive adsorption bed upstream of the biofilter could sufficiently buffer the VOC feed stream during the regeneration process.

Additionally, preparation for pilot testing the SMZ/VPB system in the field began. Design of the pilot system was completed and pre-field construction and testing was done in the laboratory. Operation, sampling and analysis and regeneration procedures for the pilot test were developed based on previous work done by the PIs in the Wyoming field test. A cost survey, feasibility assessment and cost analyses were also completed to investigate the long term effectiveness of the SMZ/VPB system to treat produced water for re-use. Several factors were investigated including: current costs of treatment and disposal of produced water, end-use water quality requirements, and state and federal permitting requirements.

\section{Buffering Experiments - Materials and Methods}

Results of our previous experiments demonstrated that a biofilter packed with compost-based materials could effectively treat the waste gas stream generated when a saturated SMZ bed is regenerated. However, regeneration tests with the SMZ indicate that the BTEX concentrations are initially too high to be completely degraded in the VPB at a reasonable EBCT of one minute. The VOC concentrations during the first several 
hours of the SMZ regeneration process are typically on the order of several thousand $\mathrm{ppm}_{\mathrm{v}}$ and drop exponentially over the remaining 6 to 10 hours of the regeneration period. It is desirable to employ a buffering column to reduce the peak VOC concentrations during the beginning of the regeneration period since these VOC loadings can overwhelm the biodegradation capacity of the VPB. The objective of the most recent series of experiments was therefore to determine if a SMZ or granular activated carbon (GAC) buffering column could reduce the high concentrations of BTEX observed in the early stages of SMZ regeneration. To this end, a series of experiments were conduced with a lab-scale buffering column containing either SMZ or GAC.

\subsection{Buffering Column Design and Operation}

\subsubsection{SMZ Buffering Column}

Two liters of SMZ (4-6 mesh) were packed in a buffering column (ID $16.2 \mathrm{~cm}$, stainless steel). Within the packed column, a perforated stainless steel plate was installed at the bottom of the packing to support the SMZ. Contaminant-free air (average relative humidity below 10\%) flowed through a pressure regulator. Liquid toluene (ACS reagent grade, Sigma, St, Louis, MO) was delivered by a syringe pump (KD Scientific, Boston, MA) and evaporated into the inlet air stream that was fed to the top of the buffering column. The air flow rate was maintained at $12 \mathrm{~L} / \mathrm{min}$ resulting in a 10 sec empty bed contact time (EBCT) in the buffering column. All experiments were conducted at the ambient laboratory temperature of $23^{\circ} \mathrm{C}$. A saturation test was done to determine the adsorption capacity of the virgin SMZ for VOCs and to prepare for the following spikefeed experiments. In the saturation test, $920 \mathrm{ppm}_{\mathrm{v}}$ toluene was introduced to the buffering column continuously until it reached the equilibrium state. After a steady outlet concentration was observed for a period of 4 hours, the toluene injection to the feed stream was discontinued and clean air was passed through the column at a flow rate of 12 $\mathrm{L} / \mathrm{min}$. The concentration of toluene exiting the buffering column was then monitored until it dropped below the $5 \mathrm{ppm}_{\mathrm{v}}$. 
After the saturation test was completed, a spike feeding test was conducted with the same SMZ column for a period of eight hours. In this spike feeding test, an initial peak concentration $\left(1000 \mathrm{ppm}_{\mathrm{V}}\right)$ of toluene was supplied to the bioreactor for a period of 15 minutes; the toluene concentration in the inlet waste gas stream was then decreased exponentially over the next 8 hours (see Figure 2). After eight hours, the toluene feed to the column was discontinued; $12 \mathrm{~L} / \mathrm{min}$ of clean air was provided to the column and the outlet concentration from buffering column was measured continuously to monitor the desorption of toluene from the SMZ.

\subsubsection{GAC Buffering Column}

Granular activated carbon (GAC) was also investigated as an adsorbent for use in the buffering column. In these tests, $200 \mathrm{~mL}$ of virgin GAC (4-10 mesh, Calgon Carbon Corp., Pittsburgh, PA) was packed in a buffering column (ID $10.16 \mathrm{~cm}, \mathrm{PVC}$ ). Contaminant-free air (average relative humidity below 10\%) flowed through a pressure regulator at $12 \mathrm{~L} / \mathrm{min}$ resulting in a 1 sec empty bed contact time (EBCT) in the buffering column. All experiments were conducted at the ambient laboratory temperature of $23^{\circ} \mathrm{C}$. Just as in the previous SMZ buffering test, the adsorption capacity of the virgin GAC was determined by introducing $1000 \mathrm{ppm}_{\mathrm{v}}$ of toluene to the buffering column continuously. After a steady outlet concentration was observed in the buffering column, the toluene feed was disconnected and clean air was introduced to the column while the outlet toluene concentration was monitored. Following the saturation test, a series of toluene spike-feed tests were conducted. The toluene concentration profile for each spike test was identical to that described earlier for the SMZ column (e.g., 1000 ppmv toluene initially with an exponential decline in inlet concentration over the next 8 hours). Following each 8 hour spike-feed period, the toluene injection was discontinued and clean air was fed to the buffer column for a period of 16 hours. To determine how the system would respond to repetitive cycles of toluene spike-feeds, this 8 hours on/16 hours off pattern was repeated several times until a steady response from the system was observed. 


\subsection{Analytical Methods}

For the SMZ buffering column, gas samples were collected from sampling ports located on the inlet and outlet sides of the buffering column to determine the toluene concentration in the air stream entering and exiting the buffering column. Samples were collected with gas-tight syringes and immediately analyzed using a gas chromatograph equipped with a flame ionization detector. For the GAC buffering column, a portion of inlet gas and the outlet gas from the buffering column were diverted via Teflon sampling lines to total hydrocarbon (THC) analyzers (3000 HD heated FID, K2BW Environmental Equipment Co.). The THC analyzers were calibrated with a certified methane standard and were used to continuously monitor the total hydrocarbon concentration in the gas streams.

The pressure drop across the buffering column was measured periodically using a pressure gauge (Magnehelic, Dwyer Instrument Inc., IN). The gauges were connected directly to the inlet and outlet gas sampling ports, and the pressure difference was measured in inches of $\mathrm{H}_{2} \mathrm{O}$. Relative humidity and temperature of gas were measured by a traceable hydrometer/thermometer (Fisher scientific, Pittsburgh, PA).

\section{Results and Discussion}

\subsection{Buffering Tests with SMZ}

\subsubsection{Saturation Test}

During the saturation test of the virgin SMZ, the buffering column was supplied with a constant inlet toluene concentration of $920 \mathrm{ppm}_{\mathrm{v}}$ for a period of 4.5 hours. The exit toluene concentration as a function of time is displayed in Figure 1. Within one hour, the SMZ was saturated with toluene despite a relatively long EBCT of 10 seconds. In contrast, the desorption of toluene following the discontinuation of toluene feed to the column on hour 4.5 was relatively slow. Using a rough integration method, the adsorbed quantity of toluene on the SMZ at saturation was approximately $0.39 \mathrm{mg}$ toluene per gram of SMZ. 


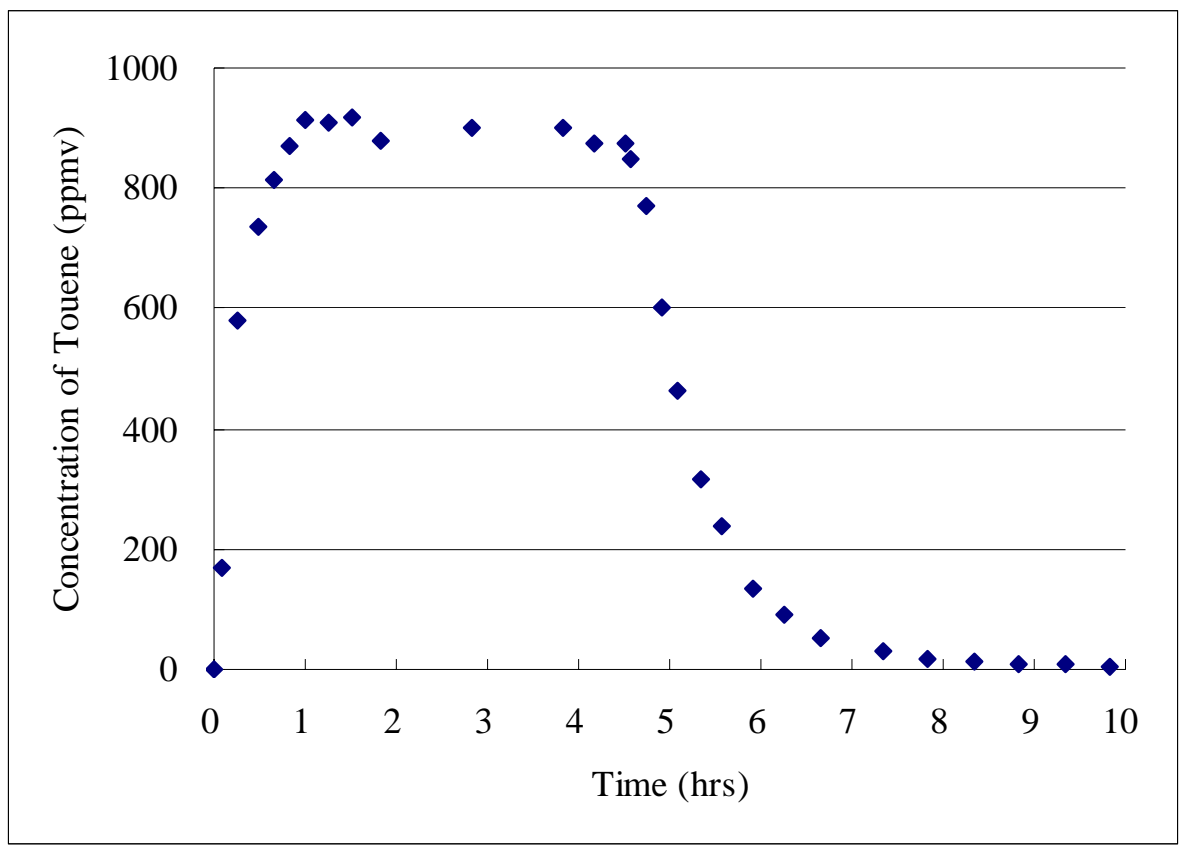

Figure 1. Pre-saturation of SMZ with toluene

\subsubsection{Spike Feed Test}

Figure 2 summarizes the results of the spike-feed test that was conducted with the SMZ column. A programmable syringe pump was used to inject the appropriate quantity of toluene into the air stream entering the SMZ buffering column to achieve the desired inlet toluene concentration as a function of time (pink/square symbols in Figure 2). (The accuracy of this method was confirmed in previous tests in which the expected inlet concentration based on the syringe pump injection rate was compared to that measured continuously with a THC analyzer.) As evident in Figure 2, the maximum outlet concentration from the buffering column was approximately $630 \mathrm{ppm}_{\mathrm{v}}$. Considering the duration of the 1000 ppmv peak was only 15 minutes, this buffering capacity is minimal and would not be sufficient to prevent breakthrough in a downstream vapor phase biofilter. 


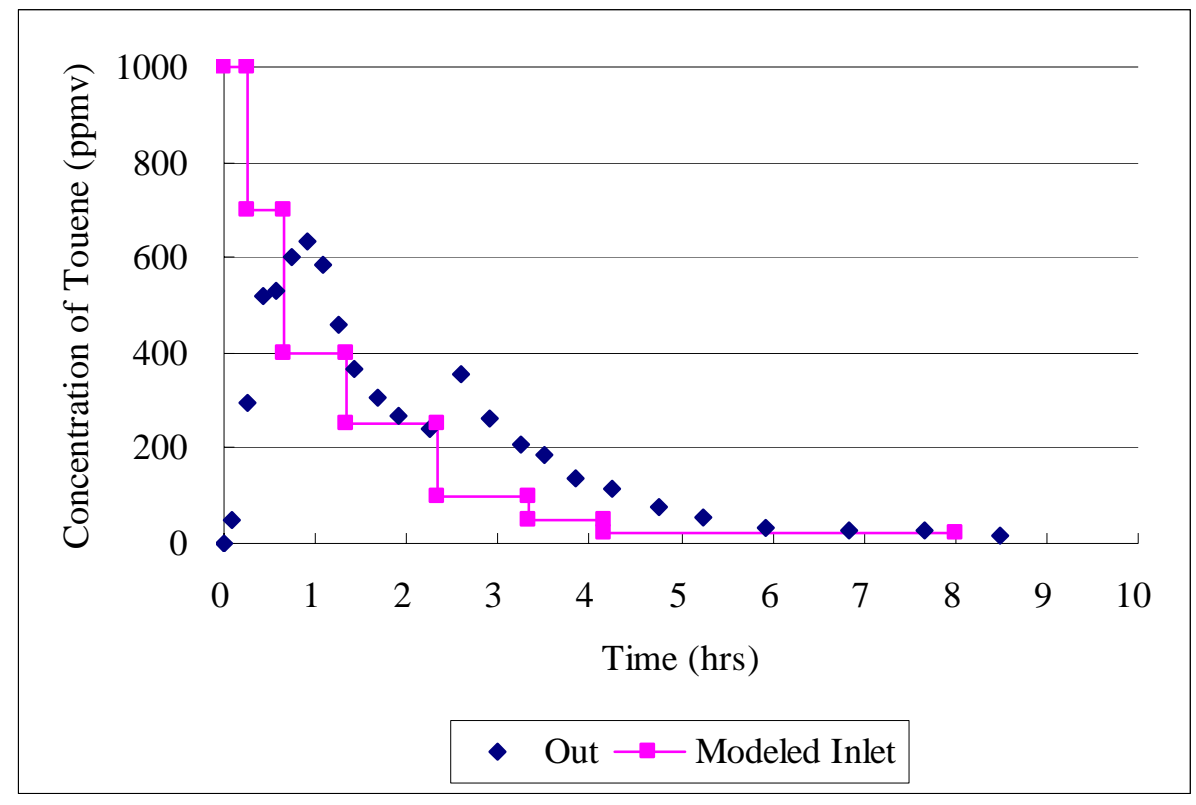

Figure 2. Response of the SMZ buffering column to a spike in toluene concentration at time 0 .

\subsection{Buffering Test with GAC}

\subsubsection{Saturation Test}

During the saturation test of the virgin GAC, the buffering column was supplied with a constant inlet toluene concentration of 1000 ppmv for a period of 22.5 hours, after which clean air was passed through the column. Figure 3 presents the outlet toluene concentration from the GAC buffering column during this test. All of the toluene introduced to the buffering column was adsorbed to the GAC during the first four hours of operation, and then gradual breakthrough occurred. The GAC saturated by 22.5 hours when both the inlet and outlet toluene concentrations were $1000 \mathrm{ppm}_{\mathrm{v}}$. After the toluene injection was discontinued, the outlet toluene concentration decreased rapidly over the next 10 hours. However, when the outlet concentration dropped below approximately $200 \mathrm{ppm}_{\mathrm{v}}$, the release of adsorbed toluene from the GAC slowed. Even after 100 hours, the outlet toluene concentration was still above $15 \mathrm{ppm}_{\mathrm{v}}$, indicating that the GAC was not completely regenerated and toluene remained adsorbed to the GAC. Nevertheless, the 
saturation test indicates that the GAC has a high affinity for toluene. Using a rough integration method of the results, it is estimated that the GAC adsorbed approximately $364 \mathrm{mg}$ toluene per gram of GAC at saturation (for a $1000 \mathrm{ppm}_{\mathrm{v}}$ toluene feed). This saturation value is three orders of magnitude higher than that observed earlier for the SMZ.

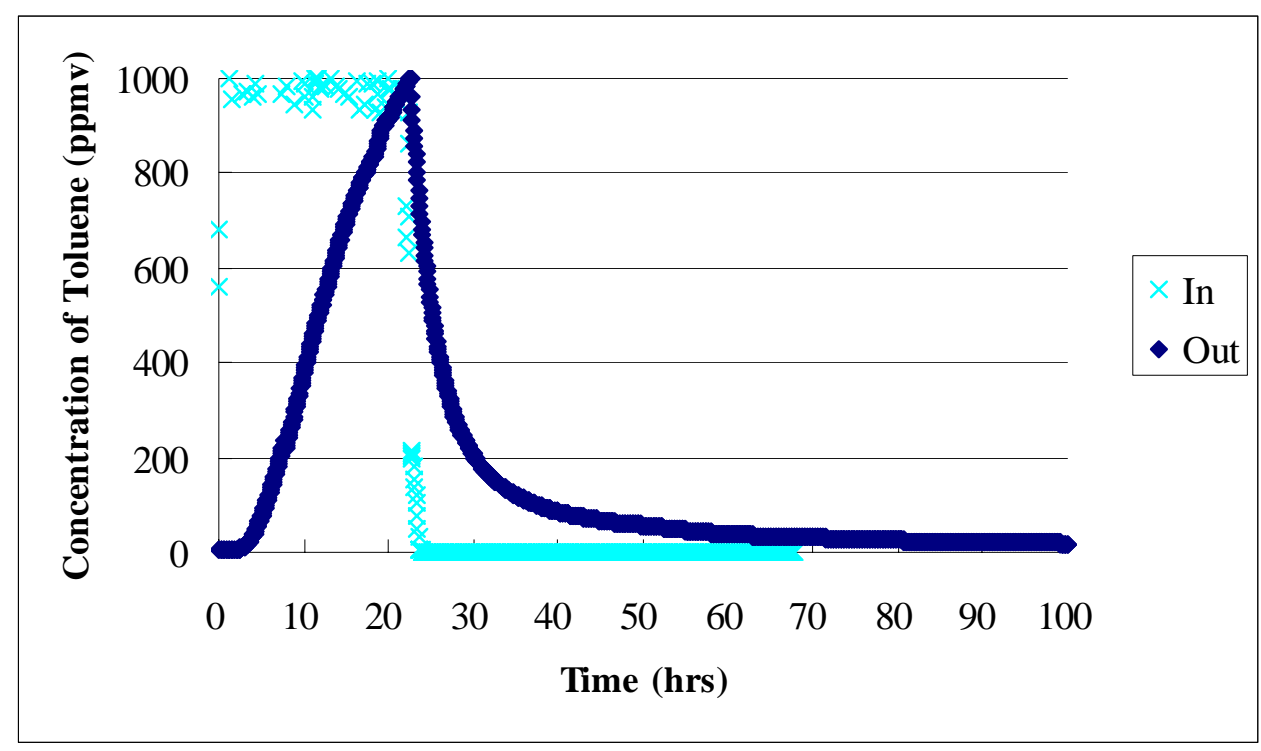

Figure 3. Pre-saturation of GAC with Toluene

\subsubsection{Spike Feed Test}

During the SMZ regeneration process, ambient air is sparged through the saturated SMZ column to remove the adsorbed BTEX contaminants. During this process, the initial contaminant concentrations in the gas stream are high (on the order of thousands of $\mathrm{ppm}_{\mathrm{v}}$ ) but drop off exponentially as the sparging process continues. To understand the capacity of a GAC buffering column to attenuate the peak VOC concentrations, the GAC buffering column used in the previous saturation test was subjected to a $1000 \mathrm{ppm}_{\mathrm{v}}$ spike in inlet toluene concentration followed by an exponential decline in the inlet toluene concentration over a period of 8 hours.

Figure 4 shows the results of this spike feeding test in the GAC buffering column. The maximum outlet concentration from the buffering column remained below $30 \mathrm{ppm}_{\mathrm{v}}$ and this value was relatively constant even after 45 hours of operation. This result implies 
that the GAC column can effectively buffer the peak VOC concentrations and prevent overloading of a downstream biofilter. The gradual release of the adsorbed chemical (toluene in this case) also ensures that a downstream biofilter would receive a steady VOC supply even if the SMZ regeneration process does occur on a cyclical basis. However, one concern with the results presented in Figure 4 is how well the GAC column would handle repeated spikes in VOC feed. This question was addressed in the experiments described below.

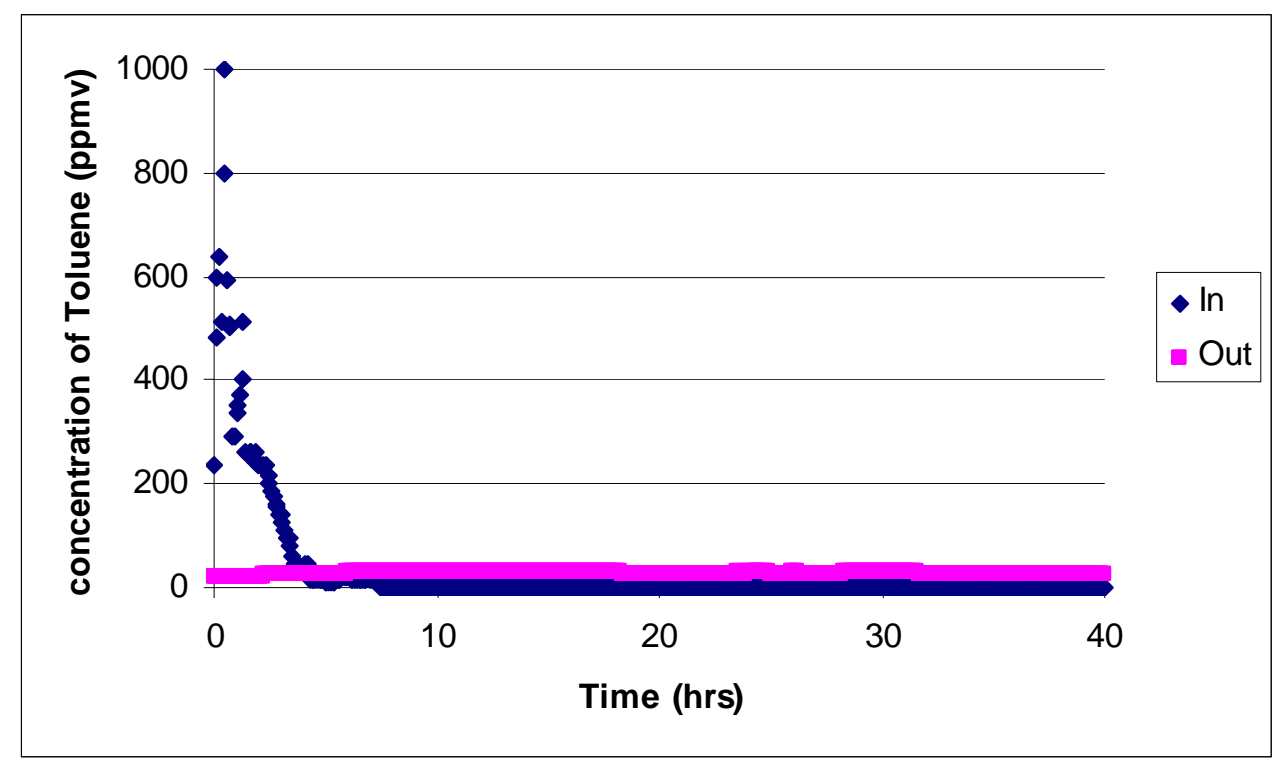

Figure 4. Toluene Spike Feed Test in the GAC Buffering Column

Repeated Spike Feed Tests. To assess how the GAC buffering column would respond to repeated toluene concentration spikes, the GAC column used in the previous experiments was subjected to seven toluene spikes/air regeneration cycles. A typical toluene concentration profile of the air entering the GAC buffering column during each of these cycles is depicted in Figure 5 and is identical to the toluene profiles used in the previous toluene spike test. 


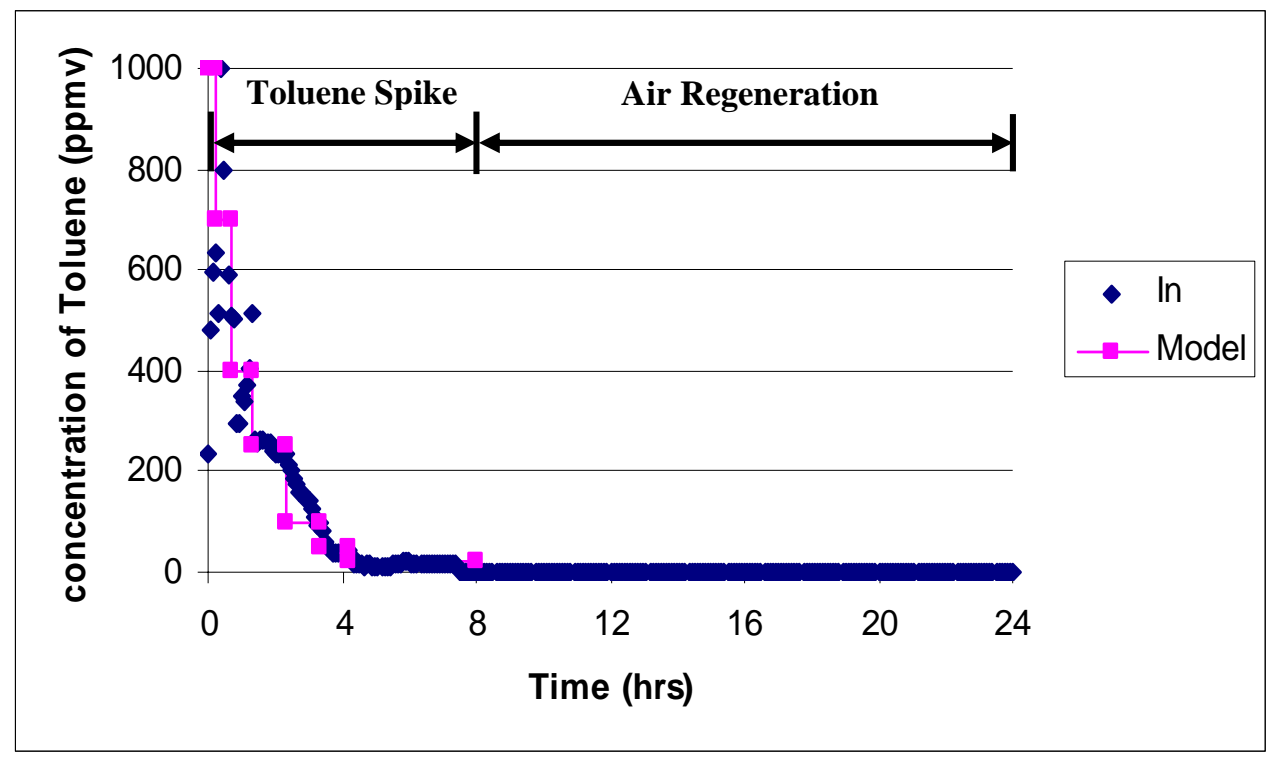

Figure 5. Toluene concentration entering the GAC buffering column during each toluene spike test. The modeled concentration (square symbols) is the calculated inlet concentration based on the programmed injection rate of toluene delivered by the syringe pump. The "In" concentration (diamond symbols) is the inlet concentration actually measured by the THC analyzer.

Figure 6A presents the inlet and outlet toluene concentrations from the GAC buffering column for each of the seven toluene spike/air regeneration cycles. Figure 6B presents the same outlet toluene concentrations on a smaller scale to provide greater detail of the variations in the outlet concentration. As evident in Figure 6A, the GAC effectively buffered the spikes in inlet toluene concentration with a maximum breakthrough concentration of 65 ppmv even though the peak inlet concentration was $1000 \mathrm{ppm}_{\mathrm{v}}$. Even though the output concentration from the GAC buffering column increased during the first five spike/air regeneration cycles, the outlet concentration eventually stabilized during the last two cycles of spike feeding (Figure 6). These results suggest that a small GAC buffering column operated at a short EBCT of 1 sec can successfully buffer the peak VOC concentrations expected during the early stages of SMZ regeneration and protect a downstream biofilter. 


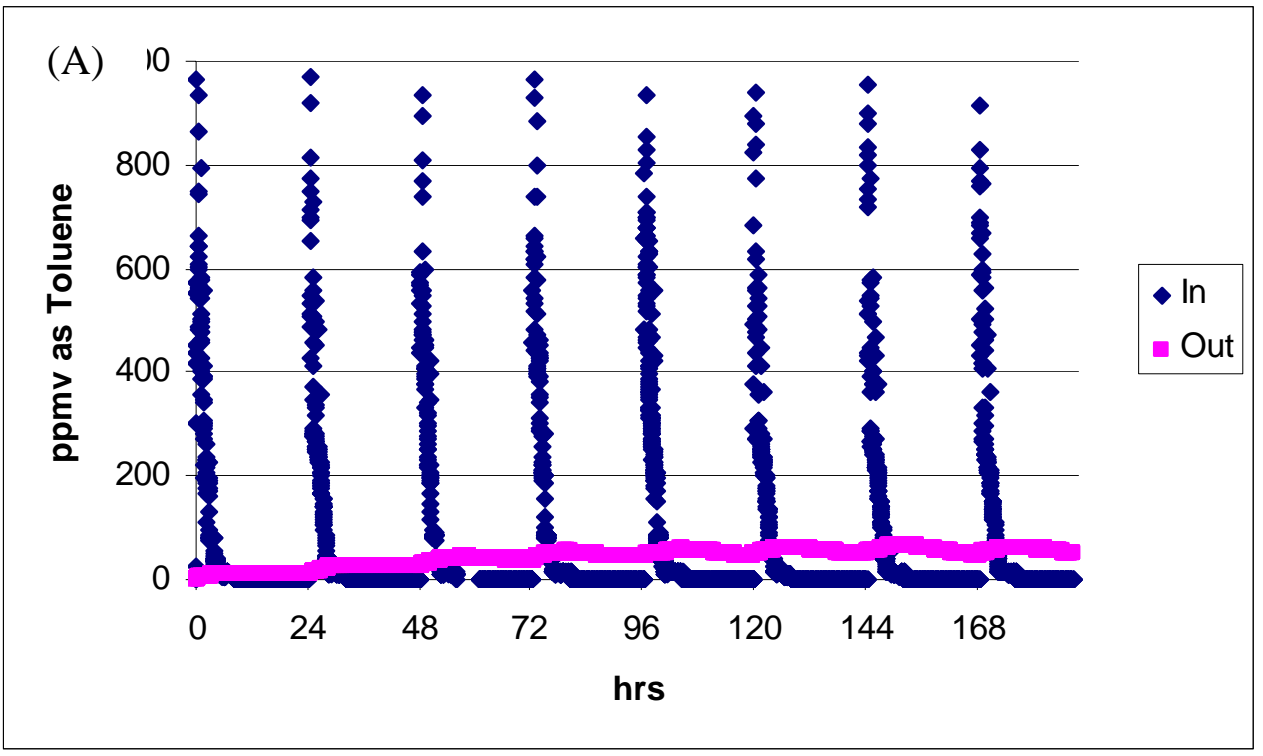

Figure 6.A. Response of the GAC buffering column to repeated toluene spikes: Inlet and outlet toluene concentrations

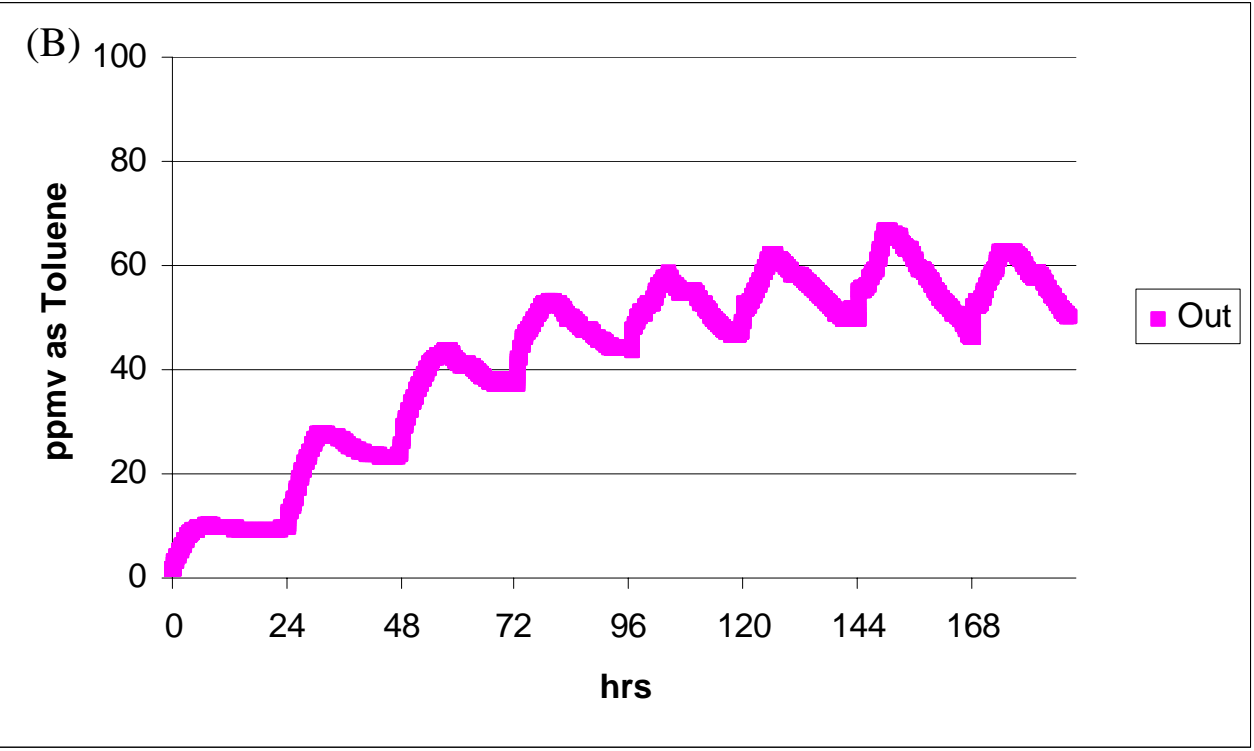

Figure 6.B. Outlet toluene concentration plotted on a smaller scale to show detail. 


\section{4. $\quad$ Pilot-Scale SMZ System Design}

\subsection{Design Criteria}

The original pilot scale system in our previous pilot test in Wyoming, 2002 used two different size columns: (1) 14” diameter and 48” height, and (2) 12” diameter and 44” height. These columns were operated at average flow rates of 25 and 19 gph, respectively (Ranck et al., 2005). Although these columns performed well, it was decided to simplify the operation of the system to use two identical columns. For this reason, the produced water treatment system that will be used in the pilot test of the process in New Mexico next summer will consist of two columns in series. The columns were originally designed for ion exchange but the ion exchange resin was replaced with surfactant-modified zeolite (SMZ) for our project. The column design disperses the influent stream at the top of the SMZ and collects the effluent at the bottom via a perforated plate funneled the water up a 1" PVC pipe to the effluent port. The influent port and the bottom collection plate both have a coarse filter to prevent large debris and SMZ from clogging the lines.

Each of the columns to be used in the pilot SMZ/VPB system will be 14” in diameter and 48” in height and will have a capacity of $3.7 \mathrm{ft}^{3}$. Each column will hold approximate 170 lbs of 14-40 mesh SMZ, and will contain a 3” headspace below the inlet manifold. The pipe in and out of column will be in 1”, and three sample ports will be installed: one for the influent of the first column, one for the effluent of the first column (also the influent of the second column), and the other for the effluent of the second column, as shown in Figure 7. Several quick-disconnect valves will be added to the system to allow a SMZ column to be disconnected quickly when it is ready for regeneration via air-sparging. The configuration of the SMZ/VPB system during the air regeneration of the SMZ system is shown in Figure 8. 


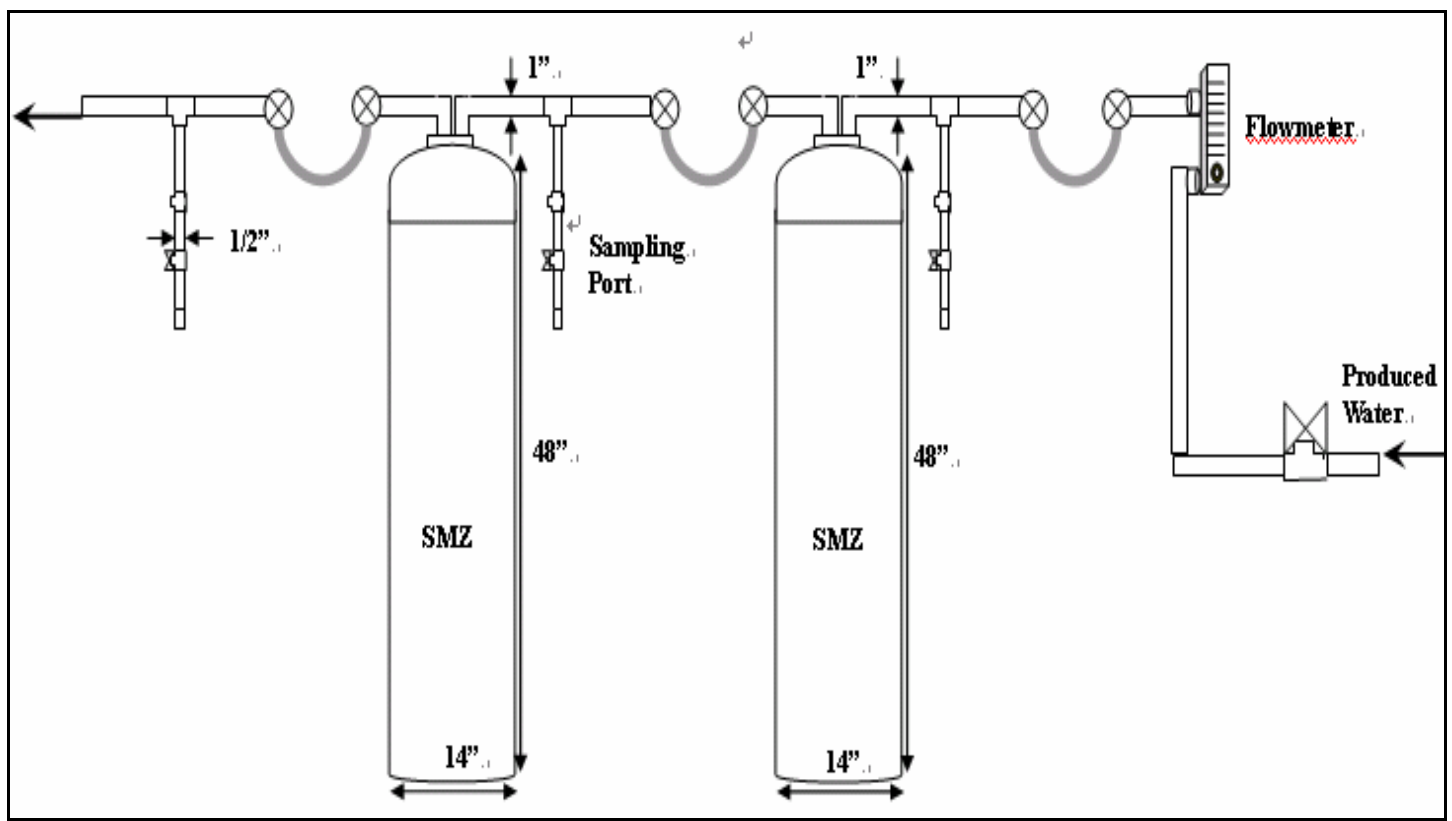

Figure 7. Schematic diagram of SMZ reactors treating produced water

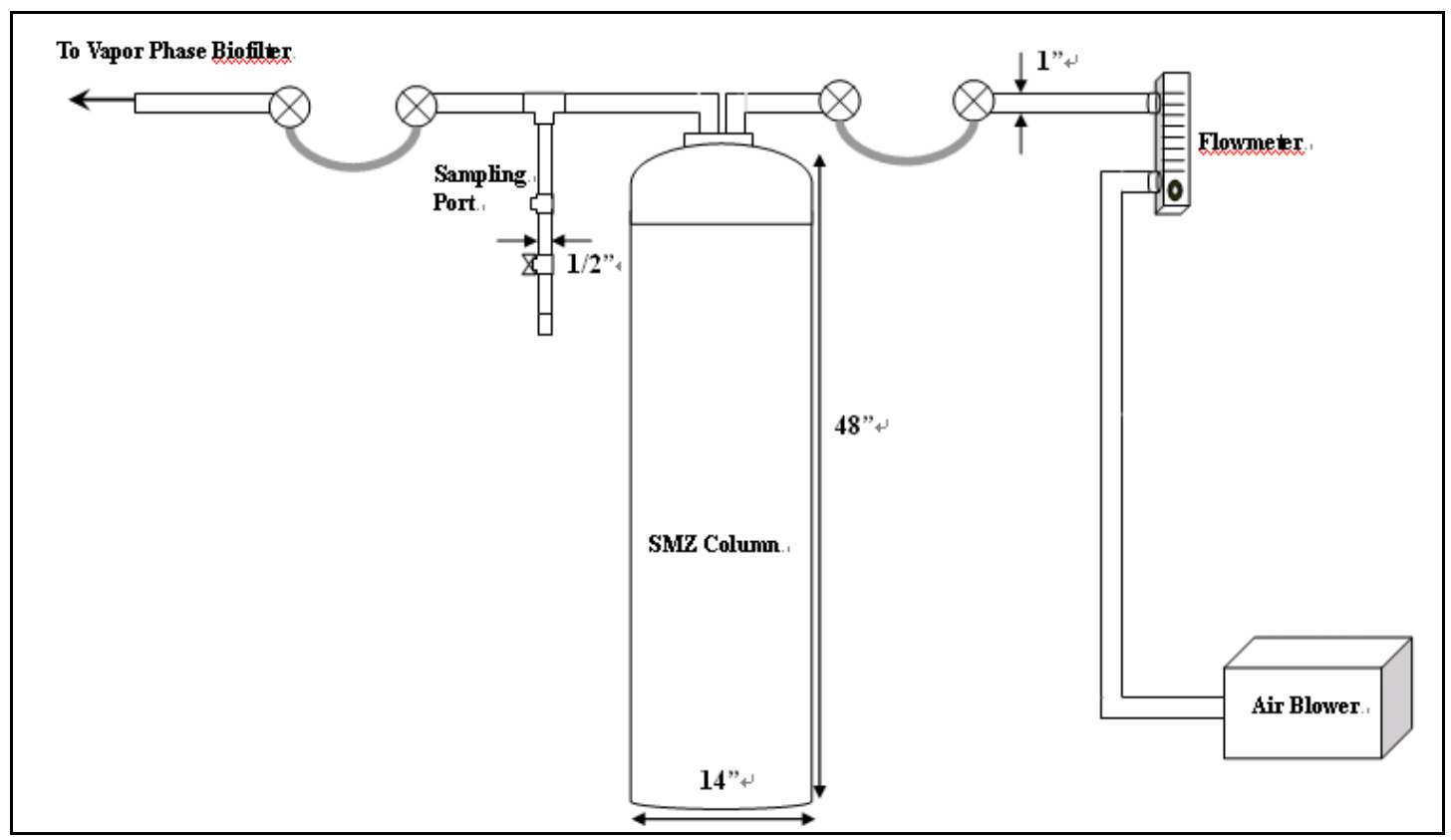

Figure 8. Schematic diagram of a saturated SMZ column being regenerated via air sparging.

\subsection{Operation of the Pilot Scale SMZ System}

The operational flow rate of the produced water treatment system will be 25 gph initially. This design rate was used successfully in the previous pilot test conducted in 
Wyoming and will serve as a starting point for the pilot test to be conducted in New Mexico this summer. The system will be operated continuously until the first column reaches saturation. Once the first column reaches saturation, the produced water feed to this column will be discontinued and the column will be drained. The second column will remain on line treating the produced water until it reaches saturation and the column that is being regenerated is ready to go back on line. The first saturated column will be regenerated by blowing clean air through the column - the contaminated waste gas system will then be directed to the passive buffering column described earlier in Sections 2 and 3 before being treated in the VPB. Based on previous laboratory scale experiments, the target air regeneration flow rate will be $15 \mathrm{~L} / \mathrm{min}$. This flow rate is sufficient to remove the BTEX contaminants from the SMZ column and yields a 1 minute EBCT in the vapor phase bioreactor which is needed to get greater than $90 \%$ removal of the BTEX contaminants.

\subsection{Sampling and Analysis}

During the field test, influent and effluent water samples will be collected from the sample ports to capture the breakthrough of the contaminants through the first SMZ column prior to saturation. The analyses of the water samples will be performed both on site and off site. For the on-site analyses, a GC-FID will be used to analyze the VOCs present in the produced water as well as those present in the contaminated air stream generated during the SMZ regeneration process. To analyze the VOCs in the produced water samples, a heating block will be used to heat the samples to $80^{\circ} \mathrm{C}$ for 15 minutes in sealed vials to drive the VOCs into the headspace. A sample of the VOCs present in the headspace will then be captured in a gas-tight syringe which will be injected into the GC/FID for analysis. The target analytes for the on-site GC/FID are the BTEX compounds. To characterize the remaining constituents in the produced water, off-site analyses will be conducted. These analyses will include VOCs, SVOCs, organic acids and TOC. 


\section{Cost survey, Feasibility and Cost Analysis}

\subsection{Cost Survey}

The majority of all produced water is the Western United States is re-injected into underground formations for disposal. These salt water disposal wells are regulated by state agencies and operated by various corporate and independent producers. The cost of disposal is a dependent upon transportation, treatment and injection costs. Treatment often includes filtration and chemical treatment for scale and corrosion control prior to re-injection. Transportation of the water may be via pipeline or more commonly by trucking to a centralized disposal site.

A producer and salt water disposal well operator in the San Juan Basin in New Mexico reported costs ranging from \$1.50 to \$4.00 per barrel during the past year. Higher costs were incurred for remote sites and increased transportation costs. These costs include transportation, filtration, chemicals and injection costs. (Personal correspondence, Nov., 2004). Deidre Boyson of B.C. Technologies, conducted a detailed survey of oil and gas producers in the Rocky Mountain Region in 2002 regarding disposal costs and methods of produced water. Cost for disposal for produced water by evaporation through open air evaporation pits ranged from $\$ 0.50 / \mathrm{bbl}$ to $\$ 1.95 / \mathrm{bbl}$ utilizing company owned pits in Wyoming. Disposal at commercial evaporation pits ranged from $\$ 1.50$ - \$4.00/bbl and included transportation costs. (D.B. Boysen, Nov. 2003). Similar costs, ranging from $\$ 1.50$ to $\$ 4.00 /$ bbl were reported for disposal via salt water disposal wells. (Personal communication, Nov., 2004). American Petroleum Institute reports disposal costs for produced water via injection wells ranging from $\$ 0.25$ to $\$ 0.50 / \mathrm{bbl}$ without transportation costs. Water that must be trucked to a disposal site incur costs of \$1.50/bbl. (http://api-ec.api.org) Transportation costs have risen drastically due to the increase in diesel fuel costs since December, 2004 which directly impacts the cost of disposal.

Treatment costs for produced water must be low enough to encourage oil and gas producers or potential end users to incorporate treatment options into their processes. However, treatment costs largely depend on the designated end use and influent water quality. The surfactant modified zeolite adsorption/vapor phase bioreactor (SMZ/VPB) 
system will provide an inexpensive method for removing volatile organic compounds. Coupled with standard desalinization techniques and pre-treatment options, cost comparisons can be made with other treatment options.

\section{2 $\quad$ Feasibility}

The feasibility and final design of a SMZ/VPB system to treat produced water is dependent on water quality standards prescribed by the designated end use, as well as influent water quality. For instance, re-use in oil and gas exploration and production will not require desalinization; however, use in power generation and agriculture applications will require treatment to reduce total dissolved solids. In some cases, water quality of the produced water is such that minimal treatment is required.

The advantage of the SMZ/VPB system is the removal and destruction of volatile organic compounds that promote fouling in standard desalinization techniques, such as reverse osmosis. For coal bed produced water, total dissolved solids are often low enough that once volatile organic compounds are removed, the water is often acceptable for several end uses. While some re-use of produced water has been utilized in the oil and gas industry in pressurizing formations, no surface disposal or utilization of water in other industries has occurred in the state of New Mexico (Oil Conservation Division, State of New Mexico, Aug. 2001). Augmentation of surface water with treated produced water could ease withdrawal limitations during droughts and would supply additional water for downstream users. Other industries potentially benefiting from the use of treated produced water include the power, oil and gas, construction industries and agriculture. Each of these end uses would require different water quality criteria and be regulated by different local, state and federal rules and regulations. Surface disposal would also have an immediate impact on the agricultural industry for irrigation and livestock watering. Several states in the western United States are currently utilizing produced water from coal bed methane wells for agriculture. 


\subsubsection{Discharge to Surface Waters}

Discharge to surface waters in the United States is regulated by the Environmental Protection Agency and state level agencies. All discharges must be permitted through the National Pollutant Discharge Elimination System (NPDES) permit program and must not degrade the receiving waters’ quality. Several states have also instituted additional criteria, for example, the state of New Mexico has established criteria for any discharge to surface waters regulated by the New Mexico Water Quality Control Commission (NMWQCC). The NMWQCC Regulation, Section 20.6 lists numeric criteria for discharge to surface waters (20.6.4.900 (J)); these criteria would be maximum effluent limits for any treatment process discharging produced water to surface waters in New Mexico.

In 2002, a bill was passed in the New Mexico legislature allowing for a tax credit for produced water delivered to the Pecos River to encourage oil and gas producers to treat the produced water to the point it can be utilized. Because produced water contains pollutants identified on the EPA's toxic pollutant list, operators wishing to deliver water to the Pecos River will be required to obtain an NPDES permit. NPDES permits are based on water quality standards for specific water bodies. States have the ability to set numeric standards or simply state that the incoming water does not degrade the designated uses of the surface water. Yates Petroleum in southeastern New Mexico is pursuing treatment to allow for delivering produced water to the Pecos River (Hume, moderator, 2004).

\subsubsection{Power Industry - San Juan Generating Station, Public Service Corporation of New Mexico}

Water is a critical element in the production of electricity. Power plants utilize water in cooling systems, steam generation and air pollution control. The San Juan Generating Station (SJGS), owned by the Public Service Company of New Mexico (PMN) is an $1800 \mathrm{MW}$ coal fired power plant. Over the years, the facility has worked to 
eliminate all water discharges by recycling and reuse of the water within the plant. Final aqueous waste is sent to the evaporating ponds on site, with no discharge of liquid water from the facility. Annually, the SJGS utilizes approximately 24,000 acre-ft of water, pumping nearly 18,000 gallons per minute from the San Juan River. It is estimated one of the local centralized salt water disposal facility could provide approximately 700 acre$\mathrm{ft}$ of water per year to augment water supplies (Personal communication Matt Lavery, PMN, 5/13/2005).

The primary use of water is in the cooling towers; however, water is also used in absorbers (air pollution control) and brine concentrators producing condensate as boiler feed water. The majority of the water loss experienced by the plant is through cooling tower evaporation and loss. Additional water loss occurs during boiler blowdowns, when boiler waste is sent to the evaporating ponds and in the flue gas moisture exiting the stack. The primary constituents of concern in the water influent are total dissolved solids (TDS) and chlorides due to scaling and corrosion issues in the power plant. The San Juan River typically runs between 300 and $500 \mathrm{mg} / \mathrm{L}$ TDS and 10 to $20 \mathrm{ppm}$ chlorides. SJGS conducted as study in 2002 on water sources in the San Juan Basin and reported TDS values from McGrath Salt Water Disposal site, owned and operated by Burlington Resources, prior to re-injection, averaged 22,700 mg/L TDS and 6,300 ppm chlorides (Joe Fayad, SJGS - PMN, personal communication 5/12/2005). Several scenarios have been considered by SJGS to incorporate produced water in their facility. These include direct use of produced water in the scrubbers, which can handle higher chlorides, dilution of produced water with incoming river water and treatment of the produced water.

Kent Zammit and Michael DiFilippo with EPRI studied the use of produced water in the San Juan Generating Station re-circulating cooling systems under a DOE Award, No. 41906. In their Semi-Annual Technical Progress Report (Zammit, Oct. 2004), they list the following water quality criteria by process area for the SJGS:

$\begin{array}{llc}\text { Cooling Tower Water } & \mathrm{Ca} & 1600 \mathrm{mg} / \mathrm{L} \text { as } \mathrm{CaCO}_{3} \\ & \mathrm{SiO}_{2} & 150 \mathrm{mg} / \mathrm{L} \\ & \mathrm{Cl} & 1000 \mathrm{mg} / \mathrm{L}\end{array}$




$\begin{array}{lll}\text { Absorbers } & \mathrm{Cl} & 5000 \mathrm{mg} / \mathrm{L} \\ \text { Ash System } & \text { TDS } & 2000 \mathrm{mg} / \mathrm{L} \\ \text { Brine Concentrators } & \mathrm{Cl} & 9000 \mathrm{mg} / \mathrm{L} .\end{array}$

The EPRI report evaluates ten off-the-shelf treatment technologies for treating produced water for supplemental water for SJGS. These technologies include reverse osmosis and brine concentration to reduce the chlorides and TDS. Pretreatment to reduce fouling due to mineral scale, particulate matter, biological films, non-soluble oils and colloidal matter must be included. (Zammit, October 2004). Their recommendation to treat produced water with $14,000 \mathrm{mg} / \mathrm{L}$ TDS is a combination HERO ${ }^{\circledR}$ (modified reverse osmosis) and brine concentration due to the lowest capital and operating costs of the options studied. (Zammit, October 2004). Additional produced waters from the San Juan Basin region would be mixed with McGrath waters; with McGrath providing approximate $24 \%$ of the produced water influent.

Volatile organic compounds (VOCs) are soluble organic compounds typically found in produced water. These compounds are generally aromatic organics primarily consisting benzene, toluene, ethylbenzene and xylene. Coal bed methane (CBM) wells produced water typically has less than $0.5 \mathrm{mg} / \mathrm{L}$ of these compounds, while produced water from conventional wells may run between 10 and $20 \mathrm{mg} / \mathrm{L}$ (Zammit, October 2004). The McGrath SWD site receives both conventional and CBM produced water. The water at McGrath SWD after filtration, just prior to re-injection ran as high as 22.6 $\mathrm{mg} / \mathrm{L}$ (Zammit, October 2004) which was confirmed by analysis done by researchers at The University of Texas at Austin.

Treatment of produced water via SMZ beds would remove the BTEX prior to desalinization process, such as reverse osmosis, brine concentration or electro-dialysis. Removal of these compounds should reduce the fouling of the desalinization treatment and could be done on site at McGrath or at a central collection system in the San Juan Basin.

The current issue in the San Juan Basin is delivering produced water to SJGS. A bill in the 2004 New Mexico State Legislature proposed a tax credit for construction of a pipeline and collection system in the region. However, the tax credit was not approved 
and trucking costs would be prohibitive. Matt Lavery, PMN Director of Water Resources, has investigated use of abandoned pipelines and "close-in" collection of produced water for use at SJGS; as well as satellite treatment stations resulting in smaller pipelines.

\subsubsection{Oil and Gas Industry}

The re-use of produced water in oil and gas exploration and production is used intermittently in the industry. Marathon Oil has used treated produced water for drilling operations and is primarily concerned with removing hydrogen sulfide before re-use. Typical total dissolved solids for their operations in the Indian Basin in New Mexico range between 10,000 and 15,000 ppm. (Personal communication, August, 2005) Burlington Resources, an independent producer in New Mexico, reported water quality for frac fluids and cementing requirements (Personal communication, August 2005):

$\begin{array}{lll} & \text { Frac Fluids } & \begin{array}{l}\text { Cement Water } \\ \text { Total Chlorides }\end{array} \\ \mathrm{KCl} & ---- & <3000 \mathrm{mg} / \mathrm{L} \\ \mathrm{NaCl} & 0-10 \% & <5 \% \\ \mathrm{pH} & 0-8 \% & <10 \% \\ \text { hardness } & 5 \text { to } 8.5 & 5 \text { to } 10 \\ \text { Iron } & <1000 \mathrm{ppm} & ---- \\ \text { Bicarbonate } & <10 \mathrm{ppm} & ---- \\ & <2000 \mathrm{ppm} & ----\end{array}$

Utilization of treated produced water in oil and gas operations should continue to be investigated. Use of the SMZ/VPB as a treatment option should provide acceptable water for use in drilling and exploration. 


\subsubsection{Agriculture Industry}

Irrigation \& Livestock watering

Treated produced water of appropriate salinity used in stock tanks does not require a NPDES permit. Under the 40 CFR 435, EPA Regulations, Subpart E, produced water located onshore, in the continental United States and west of the $98^{\text {th }}$ meridian that is good enough quality for wildlife or livestock watering or other agricultural uses can be discharged to the surface; as long as the oil and grease content is less than $35 \mathrm{mg} / \mathrm{L}$. If produced water is used for irrigation or livestock watering these criteria should be met.

The 2005 revision of New Mexico Water Quality Rule 20.6.4 NMAC (20.6.4.900 (D)), sets the following numeric criteria apply for Irrigation and Irrigation Storage:

1) dissolved selenium $0.13 \mathrm{mg} / \mathrm{l}$

2) dissolved selenium in presence of $>500 \mathrm{mg} / \mathrm{L} \mathrm{SO} 40.25 \mathrm{mg} / \mathrm{l}$

From subsection (J): (ug/L)

$\begin{array}{lc}\text { Aluminum } & 5000 \\ \text { Arsenic } & 100 \\ \text { Boron } & 750 \\ \text { Cadmium } & 10 \\ \text { Chromium } & 100 \\ \text { Cobalt } & 50 \\ \text { Copper } & 200 \\ \text { Lead } & 5000 \\ \text { Molybdenum } & 1000 \\ \text { Vanadium } & 100 \\ \text { Zinc } & 2000\end{array}$

No organic chemicals, such as benzene, toluene or ethylbenzene have a numeric criteria listed.

The same rule lists numeric criteria for livestock watering: From subsection (J): $\quad(\mathrm{ug} / \mathrm{L})$

Aluminum $\quad 500$ 


$\begin{array}{lc}\text { Arsenic } & 20 \\ \text { Barium } & 10 \mathrm{mg} / \mathrm{L} \\ \text { Boron } & 5000 \\ \text { Cadmium } & 5 \\ \text { Chromium } & 1000 \\ \text { Cobalt } & 1000 \\ \text { Copper } & 500 \\ \text { Fluoride } & 2 \mathrm{mg} / \mathrm{L} \\ \text { Lead } & 100 \\ \text { Mercury } & 10 \\ \text { Nickel } & 250 \\ \text { Nitrate+Nitrite } & 132 \mathrm{mg} / \mathrm{L} \\ \text { Vanadium } & 100 \\ \text { Selenium } & 50 \\ \text { Zinc } & 5 \mathrm{mg} / \mathrm{L} \\ \text { Adjusted gross alpha } & 15 \mathrm{pCi} / \mathrm{L} \\ \text { Radium 226+Radium } 228 \mathrm{30.0} \mathrm{pCi} / \mathrm{L} \\ \text { Tritium } & 20,000 \mathrm{pCi} / \mathrm{L}\end{array}$

No organic chemicals, such as benzene, toluene or ethylbenzene have a numeric criteria listed.

These criteria were established for groundwater with less than 10,000 mg/L total dissolved solids as regulated by the Water Quality Commission of New Mexico that are utilized for irrigation and livestock watering. If produced water is utilized for irrigation or livestock watering, these criteria should be expected to be met.

Use of produced water from coal bed methane wells in agriculture is generally acceptable due to low concentrations of volatile organics and total dissolved solids. Areas in Wyoming and Montana are utilizing produced water from coal bed methane wells for livestock watering and irrigation. Recent concerns dealing with soil contamination and aquifer dewatering have led to lawsuits and injunctions halting new 
drilling permits for coal bed methane extraction in southeastern Montana (Northern Plains Resource Council, Press Release, 5/31/2005).

New Mexico coal bed methane wells are generally from mature fields and produce fewer barrels of water per million cubic feet of gas than newer wells in Montana and Wyoming. (Kuipers, August, 2004). Water analysis of the New Mexico wells indicate much higher concentrations of total dissolved solids, bicarbonates and chlorides (Kuipers, August, 2004). Studies have indicated that varying levels of sodium, calcium and magnesium can drastically affect soil filtration rates. A measurement that is a standard parameter is the sodium absorption ratio or SAR.

$$
\text { SAR }=\frac{\left[\mathrm{Na}^{+}\right]}{\left(\left[\mathrm{Ca}^{2+}\right]+\left[\mathrm{Mg}^{2+}\right]\right)^{1 / 2},}
$$

with all concentrations are measured in meq/L. SAR values for end use criteria have been proposed by Tom Hayes and Dan Arthur in their report, "Overview of Emerging Produced Water Treatment Technologies” (October, 2004). In the report, they state that soils with SAR values greater than 12 suffer from decreased water penetration. Hayes and Arthur recommend the following TDS and SAR limits as a function of end use:

\begin{tabular}{|c|c|c|c|}
\hline TDS (mg/L) & 2,000 & 5,000 & $4,000-20,000 \quad 20,000-100,000$ \\
\hline SAR & 6 & $5-8$ & Highly varied Highly varied \\
\hline
\end{tabular}

\section{Irrigation Livestock CBM Water Non-CBM Water}

SAR values for produced water from the San Juan Basin in Colorado, New Mexico, Arizona and Utah ranges from 120.9 to 301.6 (Hayes, October, 2004). These values indicate treatment options for produced water from the San Juan Basin will require desalinization and possibly water softening to reduce the SAR values to acceptable limits for use in irrigation.

If the use of the treated produced water in the agricultural industry is deemed as a "beneficial use" to the end-user, instead of a method of disposing of the produced water, 
then appropriate water rights to the water must be identified and use granted. In many of the western states where this is already been done, such as Montana and Wyoming, operators must have surface owner agreements and groundwater appropriation rights. (ALL Consulting, 2004) This will also apply to water rights owners in New Mexico. As long as the produced water is not being utilized for individual beneficial use and is disposed of in accordance with Rule 19.15.9.715 Disposition of Produced Water by Use water rights should not be an issue. However, if a well head treatment is developed and treated water is disposed of on the land surface or sub-surface, water rights issues and surface owner agreements will need to be addressed.

\subsubsection{Feasibility Summary}

Produced water is a viable water resource for several uses in the arid western states, including surface discharge, power production, oil and gas exploration and production and agricultural uses. Each end use will define the water quality and regulatory limits on total dissolved solids and volatile organic compounds. Produced water from coal bed methane wells have received a lot of attention due to their low TDS and VOC's; however, water from CBM wells in New Mexico must first be treated to reach levels acceptable for disposal.

\subsection{Cost Analysis}

In 1995, the American Petroleum Institute organized a workshop to analyze technologies for treating produced water toxicity (API, 1995). Table 1 below provides a brief summary of the treatment technologies discussed, including the estimated costs associated with each. Of the technologies presented, the use of SMZ has the potential of being one of the most cost effective treatment options available. Furthermore, the SMZ system is relatively compact, does not require the storage of potentially hazardous chemicals, and could be readily adapted to an automated system. Results from the pilot test in New Mexico will be used to develop detailed cost estimates for the SMZ/VPB system. 
Table 1. Summary of Treatment Costs for Produced Water (API, 1995)

\begin{tabular}{|c|c|c|}
\hline Technology & Comments & Treatment Costs \\
\hline $\begin{array}{l}\text { Membrane } \\
\text { Filtration }\end{array}$ & Likely to require pretreatment & $\$ 1.90-2.38$ / 1000 gal \\
\hline $\begin{array}{l}\text { Carbon } \\
\text { Adsorption }\end{array}$ & $\begin{array}{l}\text { Requires deoiling pretreatment of } \\
\text { water to avoid fouling media, } \\
\text { costs w/ pretreatment estimated } \\
\text { by PWMOM }\end{array}$ & $\$ 1.19-8.33$ / 1000 gal \\
\hline $\begin{array}{l}\text { Chemical } \\
\text { Oxidation }\end{array}$ & $\begin{array}{l}\text { Cost estimated for Hydrogen } \\
\text { Peroxide system at } 50 \mathrm{ppm} \\
\text { dosage rate, ozone would be } \\
\text { double this cost }\end{array}$ & $\$ 0.20-0.40 / 1000$ gal \\
\hline Air Stripping & Off gas treatment required & $\begin{array}{l}\$ 0.03-0.05 \text { plus } \$ 0.50-1.00 / \\
1000 \text { gal }\end{array}$ \\
\hline UV Oxidation & $\begin{array}{l}\text { Designed to treat } 10,000 \text { barrels } \\
\text { per day at } 350 \text { days per year }\end{array}$ & $\begin{array}{l}\$ 350,000-\$ 600,000 \text { capital } \\
\text { costs plus } \$ 0.60 / 1000 \text { gal }\end{array}$ \\
\hline Reinjection & $\begin{array}{l}\text { Most common treatment for } \\
\text { offshore use, cost estimated by } \\
\text { the API SWIM model }\end{array}$ & $\begin{array}{l}\$ 3.00-5.00 \text { with up to over } \$ 72 \\
\text { per } 1000 \text { gal in some cases }\end{array}$ \\
\hline
\end{tabular}




\section{6. $\quad$ References}

ALL Consulting, Coal Bed Methane Produced Water Management and Beneficial Use Alternatives, Prepared for Ground Water Protection Research Foundation, U. S. Department of Energy, National Petroleum Technology Office, Bureau of Land Management, July 2003, www.ALL-LLC.com

American Petroleum Institute, "Environmental Commitment, Exploring, Drilling and Production”, http://epi-ec.api.org/environ

American Petroleum Institute. "Proceedings: Workshop to Identify Promising Technologies for the Treatment of Produced Water Toxicity.” Health and Environmental Sciences Departmental Report No. DR351. Parsons Engineering Science, Fairfax, Va. (1995).

Boysen, D.B.; Boysen, J.E.; Boysen, J.A. "Creative Strategies for Produced Water Disposal in the Rocky Mountain Region”. Presented at 2003 International Petroleum Environmental Conference. Houston, Texas. November, 2003.

Hays, T. and Arthur, D., “Overview of Emerging Produced Water Treatment Technologies.” Presented at the $11^{\text {th }}$ Annual International Petroleum Environmental Conference. Albuquerque, NM, October 12 - 15, 2004.

Hume, B.; Fesmire, M.E.; Lavery, M.; Saavedra, P. "Water Desalination and Reuse strategies for New Mexico - Water Rights Issues of Produced Water” Panel Discussion Minutes, New Mexico Water Resources Research Institute, September, 2004

Katz, L.E; Bowman, R.S; Sullivan, E.J. “Treatment of Produced Oil and Gas Waters with Surfactant-Modified Zeolite - Final Technical Report”, DOE Award Number DEAC26-99BC15221, November, 2003

Kuipers, J.R. “Technology-Based Effluent Limitations for Coal Bed Methane-Produced Wastewater Discharges in the Powder River Basin of Montana and Wyoming” Prepared for Northern Plains Resource Council, Billings, MT, November 2004.

Lide, D.R. CRC Handbook of Chemistry \& Physics. $75^{\text {th }}$ Edition. CRC Press, Boca Raton, FL. (1994)

Lo, I.M.C.; Lee, S.C.H.; Mak, R.M.K. “Sorption of Polar and Non-Polar Organics on Dicetyldimethylammonium-Bentonite.” Waste Management and Research. 16 (2) (1998) 129-138. 
Northern Plains Resource Council, Billings, MT, Press Release, May 31, 2005, www.northernplains.org

Oil Conservation Division, State of New Mexico, "Oil Conservation Division, ProgramOverview”, www.ocd.state.nm.us

Ranck, J.M.; Bowman, R.S.; Weeber, J.L.; Katz, L.E.; Sullivan, E.J. “BTEX Removal from Produced Water Using Surfactant-Modified Zeolite.” J. Environ. Eng., Vol 131, No. 3, 434-442 (2005)

Zammit, K.; DiFilippo, M. "Use of Produced Water in Recirculating Cooling Systems at Power Generating Facilities, Deliverable Number 3 - Treatment and Disposal Analysis”; Semi-Annual Technical Progress Report, October, 2004. Department of Energy Award No. 41906 